one-day meeting on interlibrary loans and the use of teletype. It was brought out in the discussion that Sharon Schatz from the Library of Congress has made a report on all facsimile transmission systems now being used. This report would be available to those who wrote Mr.
Paul Reimers, Information Systems Office, Library of Congress.

At the end of this discussion, the meeting was adjourned and all members boarded the bus for the ride back to Bal Harbour.-(Mrs.) Margaret Knox Goggin, Secretary, Pro Tem.

\title{
Southwest Academic Library Consortium
}

The Spring of 1967 gave birth to another cooperative venture among institutions of higher education in the Southwest. Some twenty academic libraries in New Mexico, Oklahoma and Texas entered into a Consortium. The following statements were accepted at the first two meetings, March 28, 1967 in Albuquerque and October 10, 1967 in Portales, New Mexico.

1. Each institution will prepare a list of serial holdings, giving title and volumes held, and will send this list to all libraries in the combination.

2. A program of mutually exclusive serial purchase will be established, participation to be voluntary.

3. The institutions will explore the possibilities of specializing in the acquisition of serials by subject fields.

4. Upon the request of the librarian in any institution in the combination, a library will Xerox the contents pages of designated serials and will mail to the requesting library. A fee of ten cents will be charged for each page. Faculty members receiving contents pages may check articles they want their library to request via interlibrary loan.

5. A simple tally record of interlibrary loan transactions will be maintained by each institution. An annual exchange of records and billing, if so desired, at ten cents per page was agreed upon.

The annual year will be the Gregorian calendar year. Teletype messages will also be accepted in addition to regular interlibrary loan forms and checked contents page copies as request forms.

6. Several institutions already have TWX installations and others are anticipating installations. ALL institutions in the Consortium were asked to explore the possibility of teletype. If library use alone could not justify the expense a combined effort of the entire institution was urged.

Federal Grants under Type $C$ of the Higher

Education Act based on the Consortium were received by five libraries for a total of $\$ 152$,200.00 .

For the present, formal membership in the Consortium will be limited to academic insti- tutions of higher education. The Consortium will have two meetings each year, one in the Fall and one in the Spring. The place will change from one institution to another with the specific location of the next meeting to be decided at a regular meeting of the Consortium. The chairman for each meeting will be the head librarian of the institution following alphabetically on a continuous rotating basis beginning with Panhandle State College.

The third meeting of the Southwest Academic Library Consortium was scheduled at New Mexico State University in Las Cruces, New Mexico, March 15. Don Richardson, librarian at Panhandle State College, will act as chairman for the Spring meeting.

\section{LIBRARY COLLEGE JOURNAL}

The Library College Journal, a Magazine of Educational Innovation, is the latest in the growing list of professional journals in librarianship. Its orientation, however, makes it of special interest to readers of CRL. Volume 1 , Number 1, dated Winter 1968, offers eighty neatly packaged pages containing pieces by Louis Shores on modern media, methods, and librarians; E. J. Josey on a predominantly Negro library-college; Clarence J. Leuba on an ideal college; and University of Michigan professor of higher education Robert Blackburn on library-campus conflicts. As a welcome to the new journal, $C R L$ will reprint this last mentioned article in its May issue.

The Library College Journal, which will appear quarterly, presents several continuing departments, including reviews of innovation and experimentation, hardware and software, learning resources, community college developments, grants and proposals, architecture, and books. It is edited by Howard Clayton, and its editorial board comprises Dan W. Sillers, Louis Shores, Stafford North, Thomas Minder, Robert Jordan, and Sister Helen Sheehan. Its editorial office is at Box 173, Brockport, New York 14420. $L C J$ costs $\$ 8$ per year. 